\title{
Karakteristik Pasien Tonsilitis Pada Anak Usia 5-12 Tahun di RSPBA Bandar Lampung Tahun 2020
}

\author{
Renita Dwi Rahayu, ${ }^{1}$ Tan'im Arief ${ }^{2}$, Selvia Anggraeni ${ }^{3}$ \\ ${ }^{1)}$ Fakultas Kedokteran Universitas Malahayati Bandar Lampung, adaapahariini44@gmail.com \\ ${ }^{2}$ Departemen THT-KL Fakultas kedokteran Universitas Malahayati Bandar Lampung \\ ${ }^{3}$ Departemen Kesehatan Masyarakat Fakultas Kedokteran Universitas Malahayati Bandar Lampung
}

\begin{abstract}
ABSTRAK
Tonsilitis merupakan suatu penyakit yang sering dialami oleh seseorang terutama sering terjadi pada usia anak-anak. Berdasarkan survey dari Depkes RI tahun 2012, kejadian tonsilitis di indonesia mencapai angka sekitar 23\%. Tonsilitis akut yang tidak mendapat penanganan adekuat dapat menyebabkan tonsilitis kronis maka dari itu pentingnya untuk mengetahui karakteristik dari gejala tonsilitis agar tidak berkembang menjadi tonsilitis kronis. Tonsilitis adalah suatu peradangan yang terjadi pada tonsil yang disebabkan oleh infeksi bakteri golongan Streptococcus atau virus yang dapat bersifat akut atau kronis. Gejala yang sering muncul pada tonsilitis yaitu nyeri tenggorokan, susah menelan dan bila sudah mencapai kronis dapat menyumbat saluran pernapasan. Adapun tujuan dilakukannya penelitian ini yaitu untuk mengetahui karakteristik pasien tonsillitis pada anak usia 5-12 tahun di Rspba Bandar Lampung tahun 2020. Metode penelitian pada penelitian ini yaitu cross-sectional. Diketahui bahwa hasil penelitian pasien tonsilitispada anak gejala yang paling sering terjadi yaitu nyeri pada saat menelan (40,5\%), pasien tonsilitis pada anak sering kali ditemukan pada ukuran T2-T2 sebanyak (37,8\%), pasien tonsilitis pada anak seringkali dialami oleh laki-laki sebanyak $(71,1 \%)$. pasien tonsilitis pada anak seringkali dialami oleh usia 7-8 tahun $(48,6 \%)$, insidensi terjadinya kasus tonsilitis sebanyak 8,34\%, prevalensi terjadinya kasus tonsilitis pada anak usia 5-12 tahun sebanyak 41,1\%, pada anak usia 5-12 tahun banyak mengalami tonsilitis kronis. Karakteristik yang ditemukan pada pasien tonsilitis anak usia 5-12 tahun yaitu nyeri menelan, pelebaran ukuran tonsil T2-T2, banyak dialami oleh laki-laki dan sering terjadi pada usia 7-8 tahun, insidensi terjadinya sebanyak 8,34\%, prevalensi pada anak usia 5-12 tahun sebanyak 41,1\% dan pada anak banyak mengalami tonsilitis kronis.
\end{abstract}

Keyword : tonsilitis, karakteristik, anak

\begin{abstract}
Tonsillitis is a disease that is often experienced by a person, especially often occurs in children. Based on a survey from the Indonesian Ministry of Health in 2012, the incidence of tonsillitis in Indonesia reached around 23\%. Acute tonsillitis that is not properly treated can cause chronic tonsillitis, therefore it is important to know the characteristics of tonsillitis symptoms in order not to develop into chronic tonsillitis. Tonsillitis is an inflammation of the tonsils caused by infection with the Streptococcus group of bacteria or viruses which can be acute or chronic. Symptoms that often appear in tonsillitis are sore throat, difficulty swallowing and when it reaches chronic it can block the respiratory tract. The purpose of this study was to determine the characteristics of tonsillitis patients in children aged 5-12 years at Rspba Bandar Lampung in 2020. The research method in this study was cross-sectional. It is known that the results of the study of tonsillitis patients in children, the most common symptom of which was pain during swallowing (40.5\%), tonsillitis patients in children were often found in T2-T2 sizes (37.8\%), tonsillitis patients in children were often experienced. by men (71.1\%). tonsillitis patients in children are often experienced by ages 7-8 years (48.6\%), the incidence of tonsillitis cases is $8.34 \%$, the prevalence of tonsillitis cases in children aged 5-12 years is $41.1 \%$, in children aged $5-12$ years have a lot of chronic tonsillitis. The characteristics found in tonsillitis patients aged 5-12 years, namely swallowing pain, widening of the T2-T2 tonsil size, mostly experienced by men and often occurs at 7-8 years of age, the incidence is $8.34 \%$, prevalence in children. age 5-12 years as much as $41.1 \%$ and many children have chronic tonsillitis.
\end{abstract}

Keyword: tonsillitis, characteristics, children

Korespondensi Author: Renita Dwi Rahayu,Universitas Malahayat, adaapahariini44@gmail.com, 


\section{PENDAHULUAN}

Tonsil merupakan suatu bagian dari sistem pertahanan tubuh. Tonsil palatina adalah bagian dari Cincin Waldeyer kemudian jika terjadi suatu peradangan disebut tonsilitis. Beberapa bagian yang termasuk dalam cincin waldeyer terdiri atas susunan kelenjar limfa dan terletak di dalam rongga mulut yaitu: tonsil laringeal (adenoid) , tonsila palatina (tonsil faucial), tonsila lingual (tonsila pangkal lidah), tonsil tuba Eustachius (lateral band dinding faring/ Gerlach's tonsil). Tonsila faucial atau tonsil Palatina terletak pada bagian lateral mandibula, yaitu di antara glossopalatina dan arkus faringopalatina pada bagian kiri dan kanan belakang tenggorok dan merupakan suatu jaringan limfoid terbesar serta memiliki fungsi untuk menjaga keseimbangan cairan dan melindungi tubuh dari infeksi. Bakteri yang masuk melalui hidung dan mulut akan disaring oleh Tonsil. ${ }^{1}$

Bagian belakang dari rongga mulut dan dinding faring terdapat jaringan limfoid yang terbentuk dari beberapa organ limfatik diantaranya tonsil palatina, tonsil faringeal, tonsil lingual dan tonsil torus tubarius. Struktur limfatik melindungi jalur pernafasan dan saluran pencernaan, yang disebut cincin limfatik faringeal atau waldeyer's ring. Kumpulan jaringan ini melindungi anak terhadap infeksi melalui udara dan makanan. Jaringan limfe pada Cincin Waldeyer menjadi hipertrofi fisiologis pada masa kanak-kanak, adenoid pada umur 3 tahun dan tonsil pada usia 5 tahun dan kemudian menjadi atrofi pada masa pubertas.

Tonsilitis adalah suatu peradangan dan pembengkakan pada tonsil yang disebabkan oleh suatu infeksi bakteri golongan A.Streptococcus beta hemolitikus tetapi bisa juga disebabkan oleh bakteri jenis lain atau infeksi virus. Tonsilitis dapat terjadi pada pasien usia berapapun akan tetapi banyak kasus ditemui pada anak-anak dan usia yang paling rentan untuk terinfeksi yaitu pada usia 5-15 tahun. ${ }^{1}$ Faktor resiko tonsilitis biasanya dipengaruhi oleh adanya kebiasaan makan yang buruk pada pasien, makanan yang tidak diproses dengan higienis serta tempat penyimpanan makanan yang terbuka dapat tertempel oleh kuman. $^{2}$

Pada umumnya peradangan tonsil akan mengakibatkan tonsil membesar serta menimbulkan keluhan seperti ada yang mengganjal di tenggorokan dan kesulitan untuk menelan. Beberapa kasus pada anak-anak biasanya di temukan keluhan lain seperti mengorok saat tidur atau keluhan sesak nafas karena pengaruh besarnya tonsil dapat mengganggu jalur pernafasan. Jika peradangan telah berhasil di tanggulangi kemungkinan tonsil dapat pulih kembali seperti semula tetapi jika tidak di tanggulangi kemungkinan tidak dapat kembali sehat seperti semula dan dapat terjadi infeksi yang berulang. ${ }^{3}$

Gejala lain yang dapat di temui pada anak berupa demam, pembesaran tonsil, sulit menelan, dan pembesaran pada nodus limfatikus sekitar, mengantuk di siang hari, penurunan perhatian kurang, mengalami kegelisahan, penurunan fungsi intelektual dan berkurangnya prestasi belajar. Hal ini disebabkan oleh infeksi saluran nafas atas yang tidak mendapatkan terapi yang adekuat. ${ }^{3}$

Tonsilitis dibedakan atas beberapa klasifikasi yaitu tonsilitis akut, tonsilitis membranosa dan tonsilitis kronik. Tonsilitis akut terdiri dari tonsilitis viral dan tonsilitis bacterial. Gejala tonsilitis viral lebih menyerupai common cold yang disertai rasa nyeri tenggorok dan beberapa derajat disfagia. Dan pada kasus berat dapat menolak untuk minum atau makan melalui mulut. Penderita mengalami malaise, suhu tinggi, dan nafasnya bau. ${ }^{4}$ Sedangkan tonsilitis bacterial gejala dan tanda masa inkubasi 2-4 hari. gejala dan tanda yang sering ditemukan adalah nyeri tenggorok dan nyeri waktu menelan, demam dengan suhu tubuh yang tinggi, rasa lesu, rasa nyeri di sendi-sendi, tidak nafsu makan dan rasa nyeri di telinga karena nyeri alih (referred pain) melalui saraf N. glosofaringeus (N.IX). Pada 
pemeriksaan tampak tonsil membengkak, hiperemis dan terdapat detritus berbentuk folikel, lakuna atau tertutup oleh membran semu. Kelenjar sub-mandibula membengkak dan nyeri tekan (otalgia). ${ }^{6}$

Tonsilitis membranosa terdiri dari tonsilitis difteri, tonsilitis septik dan angina plaut Vincent. Tonsilitis difteri memiliki gejala sepert infeksi lainnya yaitu kenaikan suhu tubuh biasanya subfebris, nyeri kepala, tidak nafsu makan, badan lemah, nadi lambat serta keluhan nyeri menelan. Gejala lokal yang tampak berupa tonsil membengkak ditutupi bercak putih kotor yang makin lama makin meluas dan bersatu membentuk membran semu. Membran ini dapat meluas ke palatum mole, uvula, nasofaring, laring, trakea dan bronkus dan dapat menyumbat saluran napas. Membran semu ini melekat erat pada dasarnya, sehingga bila diangkat akan mudah berdarah. Pada perkembangan penyakit ini bila infeksinya berjalan terus, kelenjar limfa leher akan membengkak sedemikian besarnya sehingga leher menyerupai leher sapi (bull neck) atau disebut juga Burgemeester's. Tonsilitis Septik disebabkan oleh Streptococcus hemoliticus pada susu sapi, tapi di Indonesia jarang terjadi. Gejala yang timbulkan dari Angina Plaut Vincent yaitu demam sampai dengan $39^{\circ} \mathrm{C}$, nyeri kepala, badan lemah, dan kadang-kadang terdapat gangguan pencernaan. Rasa nyeri di mulut, hipersalivasi, gigi dan gusi mudah berdarah. Pada pemeriksaan tampak mukosa mulut dan faring hiperemis, tampak membran putih keabuan di atas tonsil, uvula, dinding faring, gusi, serta terdapat bau mulut dan kelenjar sub mandibula membesar. ${ }^{5}$

Tonsilitis Kronik ditandai dari hasil pemeriksaan tampak tonsil membesar dengan permukaan yang tidak rata, kriptus melebar dan beberapa kripti terisi oleh detritus. Rasa ada yang mengganjal di tenggorok, dirasakan kering di tenggorok dan napas berbau. Radang amandel/tonsil yang kronis terjadi secara berulang-ulang dan berlangsung lama. Pembesaran tonsil/amandel bisa sangat besar sehingga tonsil kiri dan kanan saling bertemu dan dapat mengganggu jalan pernapasan. ${ }^{5}$

Kejadian tonsilitis masih sering terjadi dikalangan masyarakat terutama pada anak-anak dengan berbagai gejala karakteristik yang dapat dijumpai. Hal itulah yang menarik minat peneliti untuk melakukan penelitian mengenai Karakteristik Pasien Tonsilitis di Rumah Sakit Bintang Amin Bandar Lampung Tahun 2020.

\section{METODOLOGI}

Jenis penelitian ini mengunakan metode penelitian deskriptif dengan menggunakan desain penelitian cross-sectional. Penelitian ini dilaksanakan di Rumah Sakit Pertamina Bintang Amin Bandar Lampung. Pada penelitian ini peneliti menggunakan teknik purposive sampling dimana dalam penelitian ini menggunakan 37 sampel dengan kriteria inklusi yaitu memiliki data rekam medik pasien tonsilitis yang jelas, berusia 5-12 tahun, pasien tonsilitis akut dan pasien tonsilitis kronis. Instrumen yang digunakan untuk mengumpulkan data ini yaitu data sekunder yang didapat dari data rekam medik.

\section{HASIL DAN PEMBAHASAN}

Pada penelitian ini didapatkan seluruh total sampel sebanyak 37 pasien yang telah memenuhi kriteria inklusi dan eksklusi.data yang diperoleh yaitu sebagai berikut:

Tabel 1 Distribusi Frekuensi Pasien Tonsilitis Berdasarkan Keluhan Utama

\begin{tabular}{lcc}
\hline \multicolumn{1}{c}{$\begin{array}{c}\text { Keluhan } \\
\text { Utama }\end{array}$} & Frekuensi (n) & $\begin{array}{c}\text { Persentasetase } \\
(\%)\end{array}$ \\
\hline $\begin{array}{l}\text { Nyeri } \\
\text { menelan }\end{array}$ & 15 & 40.5 \\
$\begin{array}{l}\text { Nyeri } \\
\text { tenggorok }\end{array}$ & 8 & 21.6 \\
$\begin{array}{l}\text { Demam } \\
\text { Tidur ngorok }\end{array}$ & 7 & 18.9 \\
$\begin{array}{l}\text { Sering } \\
\text { meludah }\end{array}$ & 1 & 10.8 \\
Rasa & & 2.7 \\
mengganjal & 1 & 2.7 \\
\hline
\end{tabular}




\begin{tabular}{ccc}
\hline $\begin{array}{c}\text { Keluhan } \\
\text { Utama }\end{array}$ & Frekuensi (n) & $\begin{array}{c}\text { Persentasetase } \\
(\mathbf{\%})\end{array}$ \\
\hline Sesak napas & 1 & 2.7 \\
\hline Total & $\mathbf{3 7}$ & $\mathbf{1 0 0 . 0}$ \\
\hline
\end{tabular}

Berdasarkan hasil dari 37 pasien tonsilitis yang tercatat di rekam medik Rumah Sakit Bintang Amin Bandar Lampung Tahun 2020, keluhan yang paling sering terjadi yaitu nyeri pada saat menelan $(40,5 \%)$, nyeri tenggorok $(21,6 \%)$, demam $(18,9 \%)$, tidur ngorok $(10,8 \%)$, sering meludah $(2,7 \%)$, rasa mengganjal $(2,7 \%)$, sesak napas $(2,7 \%)$.

Tabel 2. Distribusi Frekuensi Pasien Tonsilitis Berdasarkan Ukuran Tonsil

\begin{tabular}{ccc}
\hline Ukuran Tonsil & $\begin{array}{c}\text { Frekuensi } \\
(\mathbf{n})\end{array}$ & $\begin{array}{c}\text { Persentase } \\
(\mathbf{\%})\end{array}$ \\
\hline T1-T1 & 6 & 16.2 \\
T2-T2 & 14 & 37.8 \\
& & \\
T3-T3 & 10 & 27.0 \\
T4-T4 & 7 & 18.9 \\
\hline Total & $\mathbf{3 7}$ & $\mathbf{1 0 0 . 0}$ \\
\hline
\end{tabular}

Berdasarkan hasil dari 37 pasien Tonsilitis yang tercatat di rekam medik Rumah Sakit Bintang Amin Bandar Lampung Tahun 2020, perbesaran ukuran tonsil yang paling banyak dialami oleh anak-anak adalah T2-T2 (37,8\%), T3-T3 (27,0\%), T4-T4 (18,9\%), sedangkan perbesaran ukuran tonsil yang paling sedikit di alami pada anak- anak adalah T1-T1 (18,9\%).

Tabel 3. Distribusi Frekuensi Pasien Tonsilitis Berdasarkan Jenis Kelamin

\begin{tabular}{ccc}
\hline Jenis Kelamin & Frekuensi (n) & $\begin{array}{c}\text { Persentase } \\
(\boldsymbol{\%})\end{array}$ \\
\hline Laki-laki & 25 & 67.6 \\
Perempuan & 12 & 32.4 \\
\hline Total & $\mathbf{3 7}$ & $\mathbf{1 0 0 . 0}$ \\
\hline
\end{tabular}

Berdasarkan hasil dari 37 data pasien tonsilitis yang tercatat di rekam medik Rumah Sakit Bintang Amin Bandar Lampung Tahun
2020, Jenis Kelamin yang paling banyak mengalami tonsilitis adalah laki-laki $(67,6 \%)$ dan paling sedikit adalah perempuan $(32,4 \%)$.

Tabel 4. Distribusi Frekuensi Pasien Tonsilitis Berdasarkan Usia

\begin{tabular}{ccc}
\hline Usia & Frekuensi (n) & $\begin{array}{c}\text { Persentase } \\
(\boldsymbol{\%})\end{array}$ \\
\hline $5-6$ & 5 & 13.5 \\
$7-8$ & 18 & 48.6 \\
$9-10$ & 9 & 24.3 \\
$11-12$ & 5 & 13.5 \\
\hline Total & $\mathbf{3 7}$ & $\mathbf{1 0 0 . 0}$ \\
\hline
\end{tabular}

Berdasarkan hasil dari 37 data pasien Tonsilitis yang tercatat di rekam medik Rumah Sakit Bintang Amin Bandar Lampung Tahun 2020, usia yang paling banyak mengalami Tonsilitis adalah 7-8 tahun $(48,6 \%)$ dan paling sedikit mengalami tonsilitis adalah 11-12 tahun $(13,5 \%)$.

Tabel 5. Jumlah insidensi pasien tonsilitis tahun 2020

\begin{tabular}{cccc}
\hline Tahun & $\begin{array}{c}\text { Diagnosis } \\
\text { Tonsilitis }\end{array}$ & $\begin{array}{c}\text { Pasien } \\
\text { Poliklinik } \\
\text { THT-KL }\end{array}$ & $\begin{array}{c}\text { Presentase } \\
(\boldsymbol{\%})\end{array}$ \\
\hline 2020 & 90 & 1078 & $8,34 \%$ \\
\hline Total & $\mathbf{9 0}$ & $\mathbf{1 0 7 8}$ & $\mathbf{8 , 3 4} \%$ \\
\hline
\end{tabular}

Pada tabel diatas dapat dilihat bahwa berdasarkan data rekam medik di poliklinik bagian THT-KL Rumah Sakit Pertamina Bintang Amin Bandar Lampung tahun 2020 didapatkan jumlah insidensi terjadinya pasien tonsilitis sebanyak $8,34 \%$.

Tabel 6. . Prevalensi Pasien Tonsilitis Pada Anak usia 5-12 Tahun

\begin{tabular}{cccc}
\hline \multirow{2}{*}{ Tahun } & $\begin{array}{c}\text { Pasien } \\
\text { Tonsilitis } \\
\text { Usia 5-12 } \\
\text { Tahun }\end{array}$ & $\begin{array}{c}\text { Seluruh } \\
\text { Pasien } \\
\text { tonsilitis }\end{array}$ & Presentase \\
& & \\
\hline Total & 37 Pasien & 90 Pasien & $41,1 \%$ \\
\hline
\end{tabular}


Pada tabel diatas dapat dilihat bahwa berdasarkan data rekam medik di poliklinik bagian THT-KL Rumah Sakit Pertamina Bintang Amin Bandar Lampung tahun 2020 didapatkan angka prevalensi kejadian tonsilitis pada anak usia 5-12 tahun sebanyak $41,1 \%$ per 100 kejadian tonsilitis.

Tabel 7. Klasifikasi Pasien Tonsilitis Akut dan

Pasien Tonsilitis Kronis Usia 5-12 Tahun

\begin{tabular}{llcc}
\hline No. & \multicolumn{1}{c}{$\begin{array}{c}\text { Klasifikasi } \\
\text { Tonsilitis }\end{array}$} & Jumlah & $\begin{array}{c}\text { Persentase } \\
(\mathbf{\%})\end{array}$ \\
\hline 1. & Tonsilitis Akut & 9 Pasien & 24,32 \\
2. & Tonsilitis Kronis & 28 & 75,67 \\
& & Pasien & \\
\hline & Total & $\mathbf{3 7}$ & $\mathbf{1 0 0 . 0}$ \\
& & Pasien & \\
\hline
\end{tabular}

Pada tabel diatas dapat dilihat bahwa berdasarkan data rekam medik di poliklinik bagian THT-KL Rumah Sakit Pertamina Bintang Amin Bandar Lampung tahun 2020 didapatkan hasil bahwa Kejadian Tonsilitis Akut sebanyak $(24,32 \%)$ dan Tonsilitis Kronis sebanyak $(75,67 \%)$.

Hasil penelitian menunjukan bahwa pasien tonsilitis pada anak banyak mengeluhkan nyeri menelan (40,5 \%). Hal ini dijelaskan pula pada hasil penelitian yang dilakukan oleh $\mathrm{Fakh}^{3}$ pada tahun 2013 terhadap pasien di bagian THT-KL RSUP Dr. M. Djamil Padang yaitu nyeri atau sakit saat menelan (72,5\%). Tonsilitis biasanya dimulai dengan sakit tenggorok mendadak dan nyeri saat menelan. Nyeri menelan adalah indikator paling awal dari tonsilitis dan merupakan ciri khas dari terjadinya tonsilitis. ${ }^{3}$

Hasil penelitian menunjukan bahwa pasien tonsilitis pada anak sering kali ditemukan pada ukuran T2-T2 sebanyak 37,8\%. Hal ini dijelaskan pula pada hasil penelitian yang dilakukan oleh Ni Made Putri Rahayu Srikandi ${ }^{6}$ pada pasien tonsilitis kronis di RSUP Sanglah pada tahun 2015 terdapat 11 kasus dimana ukuran tonsil yang paling dominan yaitu T3-T3, tercatat 6 kasus lalu diikuti ukuran tonsil T2-T2 yang tercatat dengan 3 kasus. $^{6}$
Tonsil merupakan jaringan limfoid yang berperan membantu sistem imunitas. Tonsil yang berulang kali terkena infeksi suatu saat tidak dapat membunuh semua kuman, akibatnya kuman bersarang di dalam tonsil (fokal infeksi). Adanya infeksi berulang dan fokal infeksi menyebabkan tonsil bekerja keras melawan kuman dengan memproduksi sel-sel imun yang banyak sehingga ukuran tonsil akan membesar dengan cepat melebihi ukuran normal.

Hasil penelitian menunjukan bahwa pasien tonsilitis pada anak seringkali dialami oleh lakilaki sebanyak $71,1 \%$. Tidak ada teori yang menjelaskan hubungan secara pasti antara kejadian tonsilitis kronis dengan jenis kelamin. Faktor predisposisi kejadian tonsilitis kronis secara umum dihubungkan dengan iritasi kronis, gizi, daya tahan tubuh yang rendah, pengaruh cuaca dan higienitas mulut yang buruk.

Hasil penelitian menunjukan bahwa pasien tonsilitis pada anak seringkali dialami oleh usia 78 tahun $(48,6 \%)$. Hal ini dijelaskan pula pada hasil penelitian yang dilakukan oleh Savitri di bagian THT-KL RSUD Raden Mattaher Jambi pada tahun 2013 dari 30 orang yang di diagnosis tonsilitis kronis didapatkan 15 orang penderita berusia 5-14 tahun. Kejadian tonsilitis kronis yang lebih sering terjadi pada anak ini dihubungkan dengan belum sempurnanya pembentukan kekebalan tubuh sehingga mudah terinfeksi mikroorganisme. $^{7}$

Jumlah insidensi pasien tonsilitis di Poliklinik Rumah Sakit Pertamina Bintang Amin Bandar Lampung Tahun 2020 sebanyak 90 kasus dari total seluruh kunjungan 1084 kasus di bagian Poliklinik THT-KL dengan presentase sebanyak $8,34 \%$. Prevalensi kejadian tonsilitis pada anak usia 5-12 tahun yaitu sebanyak 37 kasus dari 90 kasus tonsilitis, memperoleh hasil sebanyak $41,1 \%$ kejadian tonsilitis pada anak usia 5-12 tahun per 100 kasus terjadinya tonsilitis.

Dari 37 sampel data rekam medik di Rumah Sakit Bintang Amin Bandar Lampung Tahun 2020 di dapatkan hasil sebanyak 8 pasien mengalami 
tonsilitis akut dan 28 pasien mengalami tonsiltis kronis. Terjadinya tonsilitis kronis pada umumnya terjadi karena komplikasi tonsilitis akut terutama jika tidak mendapat terapi yang adekuat. Selain pengobatan yang tidak adekuat, faktor predisposisi timbulnya tonsilitis kronis yaitu higien mulut yang buruk, kelelahan fisik dan makanan yang tidak diolah dengan kebersihan yang baik. ${ }^{4}$

\section{SIMPULAN DAN SARAN}

Berdasarkan penelitian yang telah dilakukan mengenai karakteristik pasien tonsilitis pada anak usia 5-12 tahun di RSPBA tahun 2020, dapat diambil kesimpulan bahwa pasien tonsilitis pada anak banyak mengeluhkan nyeri menelan. Pasien tonsilitis pada anak memiliki pelebaran ukuran tonsil sebesar T2-T2, sering terjadi pada laki-laki daripada perempuan, kelompok usia yang paling sering ditemukan yaitu 7-8 tahun. Insidensi terjadinya kasus tonsilitis sebanyak $8.34 \%$, prevalensi terjadinya kasus tonsilitis pada anak usia 5-12 tahun sebanyak $41,1 \%$ dan pasien tonsilitis paada anak

usia 5-12 tahun banyak mengalami tonsilitis kronis.

\section{SARAN}

1. Tempat pelayanan kesehatan diharapkan dapat mengadakan kegiatan promosi kesehatan tentang edukasi dan pencegahan terhadap penyakit tonsilitis. Terutama dalam hal kebersihan diri sehingga terciptanya kesadaran untuk selalu hidup sehat.

2. Hasil penelitian ini dapat di jadikan sebagai referensi tambahan dan dapat dilakukan penelitian yang lebih lanjut lagi dengan menggunakan sampel serta lokasi yang lebih besar dan berbeda sehingga dapat lebih mewakili populasi di daerah tersebut.

3. Hasil penelitian ini dapat dijadikan suatu informasi kepada masyarakat mengenai tonsilitis. Maka dari itu bagi tenaga kesehatan sebaiknya mengisi data rekam medik dengan lengkap lagi sehingga dapat menjadi evaluasi kedepannya demi menghadapi permasalahan kesehatan yang akan datang.

\section{UCAPAN TERIMAKASIH}

Ucapan terimakasih kepada dr. Sri Maria Puji Lestari, M.PD, Ked selaku Kepala Prodi Pendidikan Dokter Universitas Malahayati Bandar Lampung, Dosen Pembimbing, serta semua pihak yang telah banyak memberikan bantuan dalam penyelesaian penelitian ini.

\section{REFERENSI}

1. Wiyanto, R. J., Pelealu, O. C., \& Tumbel, R. E. C. Survei Kesehatan Tenggorokan Di Desa Tinoor Dua. e-CliniC. 2015, 3(1).

2. Sari, L. T. Faktor pencetus tonsilitis pada anak usia 5-6 tahun di wilayah kerja puskesmas bayat kabupaten klaten (Doctoral dissertation, Universitas Muhammadiyah Surakarta). 2014.

3. Fakh, I. M., Novialdi, N., \& Elmatris, E. Karakteristik Pasien Tonsilitis Kronis pada Anak di Bagian THT-KL RSUP Dr. M. Djamil Padang Tahun 2013. Jurnal Kesehatan Andalas, 2016. 5(2).

4. Adams, G. L., Boies, L. R. \& Higler, P. A. BOIES Buku Ajar Penyakit THT. 6 ed. Philadelphia: Boeis Fundmentals Of Otolaryngology. 2012.

5. Manurung, R. Gambaran Faktor - Faktor yang Berhubungan dengan Pencegahan Tonsilitis pada Remaja Putri di Akper Imelda Medan Tahun 2015. Jurnal Ilmiah Keperawatan IMELDA, 2016.1(2), p. 2.

6. Rahayu Srikandi, Ni Made Putri; Dwi Sutanegara, Sari Wulan; Sucipta, I Wayan. Profil Pembesaran Tonsil Pada Pasien Tonsilitis Kronis Yang Menjalani Tonsilektomi Di Rsup Sanglah Pada Tahun 2013. E-Jurnal Medika Udayana, [S.L.], Jan. 2016. Issn 2303-1395. Available At: <Https://Ojs.Unud.Ac.Id/Index.Php/Eum/Article/ View/18112>. Date Accessed: 26 Jan. 2021.

7. Savitri. Karakteristik Penderita Tonsilitis Kronis Yang Diindikasikan Tonsilektomi Di Bagian Tht Rumah Sakit Umum Raden Mattaher Jambi Pada Bulan Mei-juli 2013.skripsi.Jambi University. 2013. 